\title{
Domestic violence by women against their intimate partners in Nigeria
}

\author{
Chinwe R. Nwanna ${ }^{1}$ and Michael O.N Kunnuji ${ }^{2}$ \\ Department of Sociology, Faculty of Social Sciences, \\ University of Lagos, Akoka, Yaba, Lagos, Nigeria \\ chironwa@yahoo.com
}

\begin{abstract}
Victims of domestic violence (DV) are more often than not, women and children. However, studies have shown that men are also victims of DV. The main objective of this article is to assess the predictors of DV against men in Nigeria. Data were generated from the 2013 NDHS. Using SPSS version $2 \mathrm{I}$ and multivariate logistic regression analysis, the findings indicated that region, education, marital and employment status, experience of violence and partners' alcohol consumption were significant predictors of DV against men. Highly educated, divorced and separated, employed women, those respondents whose husbands/partners drank alcohol, women who had experienced domestic violence and those who resided in the North-East $(O R=7.967 ; p<0.00 I)$, North-Central $(O R=1.623$, $P<0.05)$, South-East $(O R=2.161 ; p<0.00 I)$ and South-South $(O R=1.936 p<0.00 I)$ zones were more likely than women from the South West to perpetrate violence against their husbands/partners. We recommend that couples should be counselled and educated about the dangers of domestic violence and vulnerable men should be encouraged to speak out.
\end{abstract}

Keywords: Domestic violence, husbands/partners, Intimate Partner Violence, male victims, female perpetrators

\section{Introduction and background}

The incidence of domestic violence (DV), which includes a wide range of assaultive and coercive behaviours including physical, sexual and psychological attacks, as well as economic coercion by persons against their partners or other members of their households, has been documented by several studies. The victims of domestic violence are more often than not, women and children. This explains why studies often focus on the occurrence of domestic violence in situations where women are the victims. When in 1975, Gelles and Straus, reported by Young (2014), found that women were just as likely as men to report hitting a spouse and men were just as likely as women to report getting hit, it generated a lot of controversies. Nonetheless, many other studies have shown that women are often aggressors in domestic violence (Keen, 2006; Swan, (2006); Morgan and Chadwick, 2009; Young, 20l4). Furthermore, evidence has shown that men are equally victims of domestic violence (Corry, 2002; James, 2003; Campbell, 2010; Hidden Hurt Message Forum, 2011; Hoff, 2012; Adebayo, 2014; Weinberger, 2015).

Several studies have also explored factors associated with domestic violence at the macro and the micro levels both on the part of the perpetrators and the victims. At the societal level for instance, domestic violence has been associated with the patriarchal structure found in most societies
(Eze-Anaba, 2007; Tenuche, 20II; Adebayo and Kolawole, 20I3); and gender-insensitive criminal justice system (Adebayo and Kolawole, 2013).

At the level of the individual who is involved in domestic violence as a perpetrator, studies have shown that factors such as low education/being unskilled (Envuladu et al., 20I2); use of alcohol and smoking (Yusuf et al., 20II; Envuladu et al., 20I2); and having multiple sexual partners (Envuladu et al., 2012) are associated with DV. On the part of the women who suffer DV, studies have also shown that domestic violence is associated with factors such as witnessing domestic violence between one's parents (WHO, 20I0; Nnadi, 20I2); low education (NPC [Nigeria] and ICF Macro, 2009; Adebayo and Kolawole, 2013); use of alcohol and substance abuse (WHO, 20I0; Envuladu et al., 20I2) and having multiple sexual partners (Envuladu et al., 20I2). Other factors include: being HIV positive (Envuladu et al., 20I2); contributing to the family economy (Ezeah, 20l3); and not having a full-time paid job or being dependent on the husband (Eze-Anaba, 2007; Adebayo et al, 2010; Azhar et al., 2012; Adebayo and Kolawole, 2013). Being in a polygynous family (Adebayo et al., 2010); and justifying domestic violence (WHO, 20I0) are also factors that provoke DV. Furthermore, it has been demonstrated that 
experiencing abuse as children is associated with DV (Keen, 2006).

The 2008 Nigeria Demographic Health Survey shows that 2.2 percent of the women ( $15-49$ years) interviewed had ever committed physical violence against their husbands/partners when their husbands/partners were not already physically beating or hurting them (NPC [Nigeria] and ICF Macro, 2009). Also, the 2013 DHS shows that 2.I percent of the age cohort reported committing physical violence against their partners (NPC [Nigeria] and ICF Macro, 20I4). There are observable variations in the experience of domestic violence by women against their partners when different categories of variables such as experience of domestic violence as a victim, employment status, residence (i.e., urban or rural), wealth quintile, partner's use of alcohol, and spousal age difference are considered at the bivariate level (NPC [Nigeria] and ICF Macro, 2014). From the foregoing, it has been established that men also suffer DV in Nigeria.

However, predictors of domestic violence by women against their partners have not been studied extensively. Further analysis is therefore required to show the predictors of domestic violence by women against their partners in a multivariate test. Secondly, Cheryl (2002) asserts that one of the most promising developments in the prevention and treatment of domestic violence is research on the perpetrators. This study, therefore, seeks to fill this gap. The main objective of this article is to investigate domestic violence by women against their intimate partners in Nigeria. The study aims specifically to assess the predictors of DV against men by their intimate partners i.e. wives and partners. Do age, marital status, educational level, location, place of residence and employment status of a woman predict the vulnerability of her husband/partner to DV? Can experience of DV or witnessing it between one's parents make a woman commit violence against her husband/partner? Does drunken behaviour of a man increase the risk of being abused by his wife? These are questions begging for answers in this article.

The study will bring to the fore the issues of violence against men since men rarely report their experiences. Focusing attention on correlates and motives known to predict general violence can inform understanding of violence between intimate partners (Dutton et al., 2016). The findings will assist policy makers in the formulation of policies that will minimize the psychological trauma of abused men and the protection of their human rights. It will provide critical information for the design of strategies and programmes to reduce violence against men. This empirical research on violence against men will fill important gaps in current knowledge in the areas of theoretical and methodological issues. The research will help law enforcement agents, counsellors, policy makers to better screen cases and develop interventions for the perpetrators. It will also lead to treatments for the abusers that will involve behavioural therapy. Furthermore, the study will provide more avenues for further studies in this area.

Domestic violence: Meaning, context and explanations

In this section, it will be pertinent to understand the meaning of domestic violence before delving into the review of earlier empirical studies.

\section{What is domestic violence?}

Definitions of domestic violence have evolved and broadened over time. It can be referred to as Intimate Partner Violence (IPV) or Family Violence (FV). Family violence is a broader term that refers to violence between family members, as well as violence between intimate partners. It can simply be defined as a violent confrontation between family or household members involving physical harm, sexual assault, or fear of physical harm. Morgan and Chadwick (2009) view domestic violence as acts of violence that occur within intimate relationships and take place in domestic settings. It includes physical, sexual, emotional and psychological abuses.

The UK Government (2013) provides a new definition of domestic violence and abuse as any incident or pattern of incidents of controlling, coercive, threatening behaviour, violence or abuse between those aged sixteen or over who are, or have been, intimate partners or family members regardless of gender or sexuality. The abuse can encompass, but is not limited to psychological, physical, sexual, financial and emotional forms.

In their own contribution, the National Domestic Violence Hotline (2015) describes domestic violence as a pattern of abusive behaviour in any relationship that is used by one partner to gain or maintain power and control over another intimate partner. It can be physical, sexual, emotional, economic, or psychological actions or threats of actions that influence another person. This includes any behaviour that intimidates, manipulates, humiliates, isolates, frightens, terrorizes, coerces, threatens, blames, hurts, injures, or wounds someone. Similarly, Creative Communications Group (2015) defines domestic violence as a behaviour used by one person in a relationship to control the other but adds that it can be criminal. According to the group, violence includes physical assault (hitting, pushing, shoving, etc.), sexual abuse (unwanted or forced sexual activity), and stalking. The group notes that emotional, psychological and financial abuses are not 
criminal behaviours but forms of abuse that can lead to criminal violence.

In view of the afore-stated, domestic violence, in this work, can be described as any act or behaviour that is used to control, manipulate or cause physical harm on men by their wives or intimate partners as conceptualized in the Nigerian Demographic Health Survey.

\section{Context and explanations}

Literature in women's violence is very scant. Very few empirical studies focus on women's violence. Earlier studies indicate that DV against men is a reality (NPC [Nigeria] and ICF Macro, 2009; 20I3). It occurs virtually in every society in varying degrees although it is grossly underreported (Shuler, 2010). It is shrouded by silence, fear and shame (Adebayo, 2014). Violence against women is more widely reported than violence against men by their intimate partners (Shuler, 2010) and this is because women more often than not report higher levels of repeated violence and are more likely than men to experience serious injuries (Adebayo, 20I4). Smith et al (20II) reported that 4 percent of men were victims of domestic abuse in a 2010 study conducted among over 21,000 residents of England and Wales by the UK Home Office Statistic. US Bureau of Justice Statistics demonstrated that in 1993, men were victims of about 162,870 violent crimes by their intimate partners (Rennison, 2003). This number declined to 103,220 victimizations by 2001 .

Studies have shown that there is a correlation between age of the perpetrators and DV. Klein (2009) revealed that most perpetrators were between 18 and 35 years old, with a median age of about 33 years. An U.S. study of abusers subject to police incident reports or protective orders found that 33 percent were between 20 and 29 years old, and 33.4 percent were between 30 and 39 years old (Klein, 2009).

Victim abuse of drugs and alcohol is associated with domestic violence victimization. Klein (2009) reported that in the Memphis night arrest study, 42 percent of victims were drinking or drugging the day of their assault. Adebayo (20/4) also reported a woman was jailed for two years after Belfast Crown Court was told how she lost control when she came home from work to find her husband drunk while he was supposed to be looking after their three-year-old son. Furthermore, Klein (2009) revealed that experience of DV was associated with perpetration of DV. He reported that male victims of DV homicides were much more likely than female victims to have been identified previously as abusers of their eventual killers. This implied that they had previously abused their abusers (wives/partners).
Experience of DV has been associated with female perpetration of DV against their husbands. Swan et al. found that the majority of domestically violent women also have experienced violence from their male partners. They posit that the victimization women have experienced from their male partners is an important contextual factor in understanding their motivations for violence.

In Nigeria, Adebayo (20/4) reviewed a study conducted by Dienye and Gbeneol (2009) at the General Outpatient Department of the University of Port Harcourt Teaching Hospital and found that 10.4 percent of the victims of domestic violence were men.

\section{Theoretical focus}

The theoretical anchorage of this study is eclectic derived from three theories - social learning theory by Bandura (1977), resource theory by Goode (197I) and control theory by Bostock et al (2002 cited in Hyde-Nolan and Juliao, 20I2).

\section{Social learning theory}

Social learning theory by Bandura (1977) posits that the behaviours, people exhibit, are those they have learnt from their social environments. People exhibit violent behaviours if they have been raised in social environments in which they have observed domestic violence among their parents or other authority figures with whom they identify. Observing the beating of one's mother may create in a woman the consciousness about the need to take aggression as a form of defence. This study seeks to test the hypothesis which states that irrespective of other variables, witnessing domestic violence among one's parents is a significant predictor of the occurrence of domestic violence by women against their partners.

\section{Resource theory}

Resource theory emanated from three theories viz exchange/ resource theory, social exchange theory and interpersonal resource-exchange theory (Sommer, 1994) and was propounded by Goode (197I). The theory suggests a relationship between wealth and violence. It assumes that all social systems (including the family) rest to some degree on force or the threat of force and posits that the decision making power within a given family derives from the value of the resources that each person brings to the relationship such as economic, social, personal and organizational resources. Another important principle of this theory addresses the notion of exchange. Within the family structure, people are bound to each other through ongoing transactions or exchanges (Goode, 197I). Violence is seen as an outcome of the inequity of exchange. Thus, a woman who wants to 
be the dominant person in the family and is domineering, has a good job and income and/or educated may choose to use violence to maintain the dominant position.

\section{Control Theory}

Control theory is based on the concept that many family conflicts result from an individual's need to obtain and maintain power and control within a relationship(s). It is related to resource theory. Bostock et al (2002 cited in Hyde-Nolan and Juliao, 20I2) aver that the motivation underlying abuser's behaviour is the power and control that she or he is able to exert over other members of the family. The more powerful members of families (e.g., fathers, parents, husbands) often use the threat or use of force or the threat or use of violence to obtain compliance from less powerful family members (e.g., children, wives and in this case, husbands) (Goode, 197I cited in Hyde-Nolan and Juliao, 20I2). Threats, force, and violent behaviours are intended to prohibit the less powerful members of the family from engaging in behaviour that the controlling individual does not want, while establishing a demand for desirable behaviours to occur. In addition, the abuser may feel the need to gain control over how other family members think and feel. Abusers, in an effort to maintain control over other members of the family, may use many forms of intimidation, such as coercion, isolation, economic abuse, and denial of personal blame. A wife whose husband is a drunk may want to use violence to control the drunken husband.

\section{Conceptual framework}

The figure I below presents six circles that

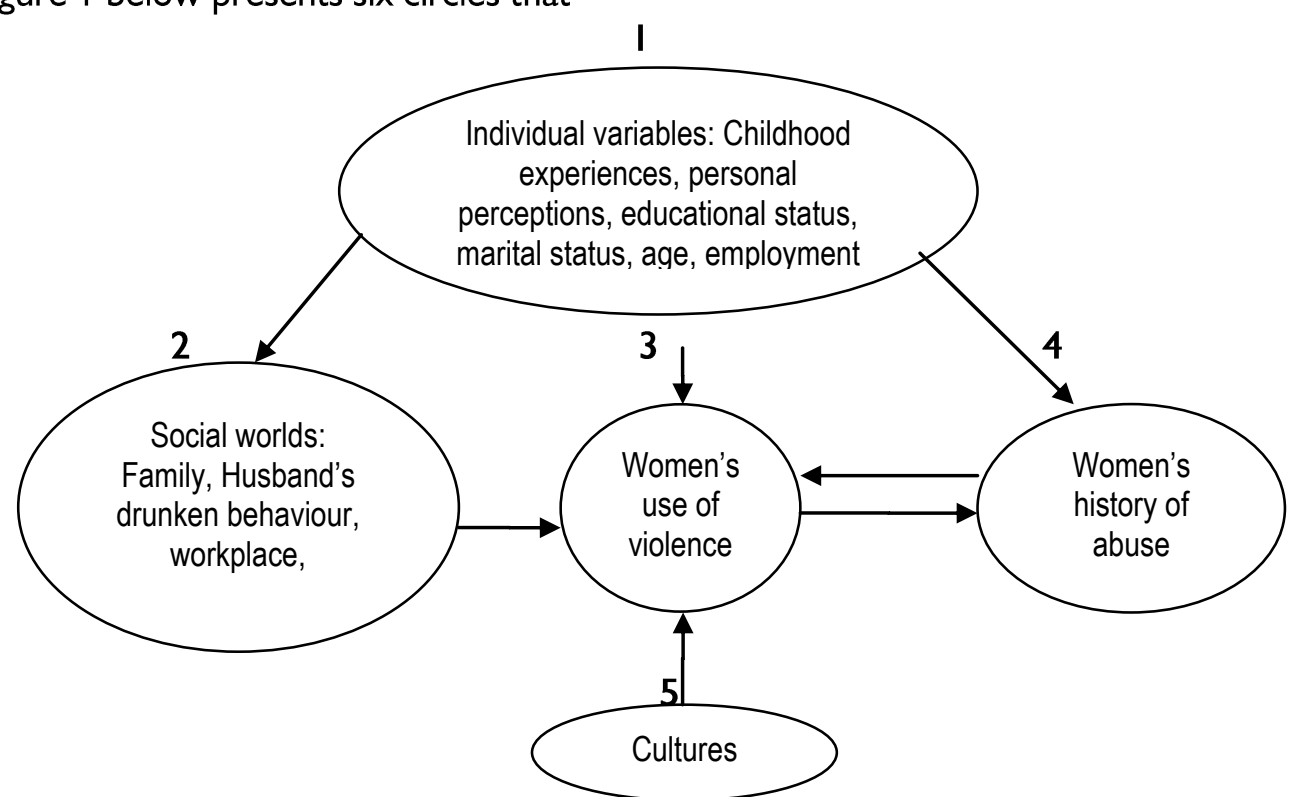

demonstrate the relationship between interactions of social, historical, individual and institutional variables in women's violence. This conceptual framework adapted the ecological model of Dasgupta (200I) of women's violence, victimization and motivations for violence.

In Circle I are the individual's variables of the women. These variables include the woman's characteristics and childhood experiences which may predispose the woman to abuse in Circle 4 and may lead to motivations for violence (Circle 3) which may include self-defence, retaliation, demanding attention, expressing anger, escape and punishment. Circle 2 describes the interactions of the individual's social worlds e.g. family, workplace etc. The interactions of these social worlds will determine her experience of being abused as well as her motivations to use violence. Circle 3 examines the women's history of abuse.

There is a bidirectional relationship between women's use of violence in Circle 3 and their male partners' violence against them in Circle 4 (Swan, 2006). Self-defense is the most common motivation of abuse found under this category as well as perceived threats against the women, their children or others (Dasgupta, 200I). Circle 5 is the cultures from which the woman comes and which impact on her life. Feminist structural theorists argue that all women who live in patriarchal cultures are limited by the female gender-roles which have an impact on how women respond to domestic violence (Dasgupta, 200I). In addition, different cultures have different norms around women's use of violence and these cultural influences have an impact on women's motivations in using violence.

Figure I: Conceptualization of the relationship between women's variables and domestic violence adapted from the ecological model of Dasgupta (200I) 


\section{Hypothesis of the study}

Witnessing domestic violence among one's parents is a significant predictor of the occurrence of domestic violence by women against their husbands/partners.

\section{Study location}

Nigeria is the most populous country in Africa with a 2006 population of more than 140 million and a growth rate of $3.2 \%$ (Federal Republic of Nigeria Official Gazette, 2007). The current population has risen to about 182 million people (Population Reference Bureau, 2015). There are about 400 ethnic groups in Nigeria with Christianity and Islam constituting the major religions (Federal Ministry of Health (FMOH), 20I0). In addition to the human resource, Nigeria is endowed with many other natural resources such as crude oil, bitumen and agricultural products. The country is a Federation, operating a 3-tier governance system at the National, State and Local Government levels. She is made up of 36 states including a Federal Capital Territory and 774 local government areas (LGAs).

For ease of administration and accelerated development, the states were divided broadly into six geopolitical zones namely North-East (NE), NorthCentral (NC), North-West (NW), South-East (SE), South-South (SS) and South-West (SW). The country lies on Africa's west coast and occupies 923,768 square kilometres of land bordering Niger, Chad, Cameroon and Benin. Nigeria is currently under a democratic government after about 30 years of military rule. She has had a mixed public/private economy since independence with the national revenue being derived mainly from crude oil. Other sources of national revenue include agriculture, industry, solid minerals and trade. The Gross Domestic Product (GDP) per capita in 2013 was 2,966 and Gross National Income (GNI) per capita in the same year was 2,663 (UN Data, 2013).

\section{Data and research methods}

The data used for this analysis came from the 2013 Nigeria Demographic Health Survey (NDHS) which is a nationally representative study of the population of Nigeria. Included in our analysis is a weighted sample of 38,948 women aged 15 to 49 years selected from the 36 states and the Federal Capital Territory (FCT) of Nigeria. Other details about the methods, sample and sampling techniques are found in the 2013 NDHS report available at the National Population Commission website (see 2013 NDHS Report). Statistical Package for Social Sciences (SPSS) version 21 was used to analyse data. Descriptive statistics were adopted to analyse the characteristics of the respondents while multiple logistic regression analysis was run to test the hypothesis and assess the predictors of IPV by women. Missing values or nonresponses were excluded from the analyses.

\section{Findings}

Respondents' profile

The 2013 DHS covered 38,948 women of $15-49$ years. Among the respondents were 20.3 percent of 15 - 19 year olds (see Table I). This is followed by those aged $20-24$ years. More than one half of the women were between 15 and 29 years old giving a mean age of 28.9 years. For marital status, more than three-fifths were married while one-quarter were unmarried.

Table I: Respondents' profile

\begin{tabular}{|l|c|c|}
\hline Respondents' Characteristics & $\mathbf{N}=38,948$ & $\%$ \\
\hline Age & & 20.3 \\
\hline $15-19$ & 7,905 & 17.2 \\
\hline $20-24$ & $6,7 \mid 4$ & 18.1 \\
\hline $25-29$ & 7,037 & 13.8 \\
\hline $30-34$ & 5,373 & 12.1 \\
\hline $35-39$ & 4,701 & 9.4 \\
\hline $40-44$ & 3,663 & 9.1 \\
\hline $45-49$ & 3,555 & \\
\hline Marital status & & 25.2 \\
\hline Never in union & 9,820 & 70.0 \\
\hline Married/ Living with partner & 27,274 & 2.5 \\
\hline Widowed & 993 & 2.2 \\
\hline Divorced/ No longer living together/separated & 861 & \\
\hline Educational level & & 35.3 \\
\hline No education & 13,740 & \\
\hline
\end{tabular}


African Population Studies Vol. 30, No. 2, (Supp.), 2016

\begin{tabular}{|l|c|c|}
\hline Primary & 7,104 & 18.2 \\
\hline Secondary & 14,407 & 37.0 \\
\hline Higher & 3,697 & 9.5 \\
\hline Currently working & & 38.0 \\
\hline No & 14,733 & 62.0 \\
\hline Yes & 24,006 & \\
\hline Place of residence & & 39.9 \\
\hline Urban & 15,545 & 60.1 \\
\hline Rural & 23,403 & \\
\hline Region & & 16.0 \\
\hline North Central & 6,251 & 17.0 \\
\hline North East & 6,630 & 24.8 \\
\hline North West & 9,673 & 11.5 \\
\hline South East & 4,462 & 15.6 \\
\hline South-South & 6,058 & 15.1 \\
\hline South West & 5,874 & \\
\hline
\end{tabular}

Others were widowed, divorced and separated. The majority of the respondents had secondary education (37.0 percent) while another 35.3 percent had no formal education. More than three-fifths of the respondents were working at the time of the survey. Similarly, three-fifths of the respondents were rural women and this may explain why majority of them had low education. For instance, more than one half of the respondents either stopped at primary education or did not go to school at all. The NorthWest region had the highest percentage of the respondents ( 24.8 percent) with no formal education, followed by North-East (I7.0 percent) and NorthCentral zones (16.0 percent). The rest were from the southern regions.

Respondents' experience of violence by the husband/partner

In order to assess the predictors of violent acts by women, the question on having ever physically hurt husband/partner when he was not hurting the respondent was adopted as the dependent variable while respondents' socio-demographic characteristics were utilised as independent variables. In addition, it was pertinent to consider if the respondents themselves had ever experienced violence by their husbands/partners. After establishing the respondents' experience of violence, two questions were asked on the severity of the violence namely whether the respondents had ever experienced less severe violence and whether they had ever experienced severe violence. For the experience of less severe violence, the respondents were asked the following questions: Ever been pushed, shaken or had something thrown at by husband/partner, ever been slapped by husband/partner and ever been punched with fist or hit by something harmful by husband/partner. Severe violence was defined as: Ever been kicked or dragged by husband/partner, Ever been strangled or burnt by husband/partner and ever been threatened with knife/gun or other weapon by husband/partner.

Table 2: Respondents' experience of violence by the husband/partner

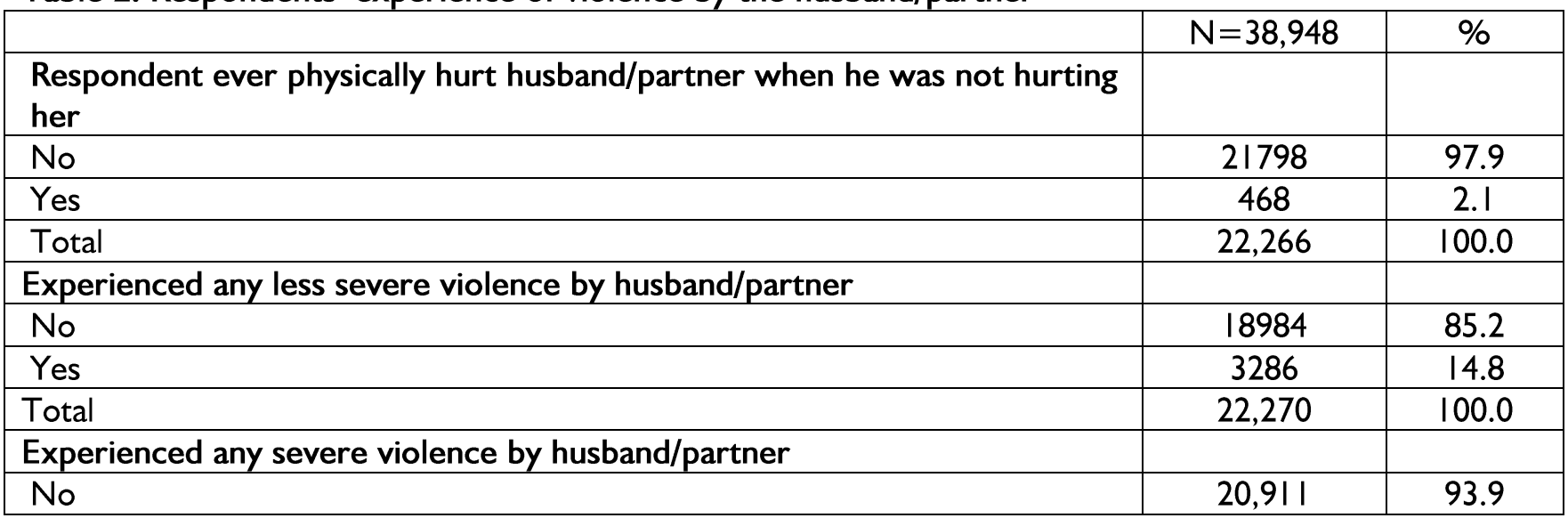




\begin{tabular}{|c|c|c|}
\hline Yes & 1347 & 6.1 \\
\hline Total & 22,258 & 100.0 \\
\hline \multicolumn{3}{|c|}{ Husband/partner drinks alcohol } \\
\hline No & 17,582 & 79.0 \\
\hline Yes & 4,665 & 21.0 \\
\hline Total & 22,247 & 100.0 \\
\hline \multicolumn{3}{|c|}{ Respondent's father ever beat her mother } \\
\hline No & 22,867 & 83.4 \\
\hline Yes & 2,880 & 10.5 \\
\hline Don't know & 1,673 & 6.1 \\
\hline Total & 27,420 & 100.0 \\
\hline
\end{tabular}

Other independent variables included in the analysis were whether the respondents' husbands/partners drank alcohol and if their fathers had ever beaten their mothers.

In Table 2 above, 468 respondents, representing about 2.1 percent of the respondents admitted that they had ever physically hurt their husbands or partners. This percentage may seem insignificant but in terms of numbers i.e. 468 , it is quite significant.

About 14.8 percent of the respondents admitted ever experiencing less severe violence such as being pushed, shaken or had something thrown at by husband/partner, slapped, punched with fist or hit by something harmful by husband/partner (see Table 2 above).

In the same vein, 6.I percent said they had experienced severe violence such as being kicked or dragged by husband/partner, strangled or burnt and threatened with knife/gun or other weapons by the husband/partner. Table 2 further shows that 21.0 percent of the respondents affirmed that their husbands/partners were in the habit of drinking alcohol. About 10.5 percent of the respondents reported that their fathers had beaten their mothers while 6.I percent could not tell whether this had happened to their mothers.

The predictors of committing violence by women against their husbands/partners

Using multivariate logistic regression analysis, the predictors of violent acts by women were examined in Table 3. The table demonstrates that location i.e. zones or regions of the country were significant predictors of women's violent acts. Women from the North-Central, North-East, South-East and SouthSouth were more likely than those in South-West [Reference category, (RC)] to hurt their intimate partners physically. Their Odds Ratios (ORs) were significant at $p<0.05, p<0.001, \quad p<0.001$ and $p<0.00$ I respectively. Women in the North-East are seven times more likely than women in the SouthWest to commit violence against their spouses. Likewise, South- Eastern women are twice likely to hurt their husbands/partners.

The multivariate logistic regression analysis shows that education is a predictor of women's violent acts. No education with OR $(0.5 / 2)$ is significant $(p<0.0 \mathrm{l})$ indicating that illiterate women are less likely than women with higher education to cause harm on their husbands/partners. In Table 3, the OR for married respondents was 0.0 .595 which is less than $I$ and it is also significant $(p<0.05)$. This means that married women are less likely than those who are no longer living with their spouses and the separated women to physically hurt their partners. Women who were no longer living together with their husbands and those separated from their partners were used as reference category (RC). For those who were not working at the time of the study, the OR is 0.737 and significant $(p<0.05)$. This is less than 1.000 and therefore unemployed women are less likely to commit violence against their spouses. In other words, employed women could inflict harm on their husbands/partners.

The OR of the respondents who said they had not experienced any less severe violence by their husbands/partners is 0.094 and highly significant $(p<0.00 \mathrm{I})$. The OR lies in between lower $(0.072)$ and upper $(0.121)$ confidence intervals. This implies that those who said they had experienced less severe violence which is the $R C$ are more likely than others to physically hurt their husbands/partners. 
Table 3: Logistic regression model predicting the likelihood of committing violence by women against their husbands/partners

\begin{tabular}{|c|c|c|c|}
\hline \multirow{2}{*}{ 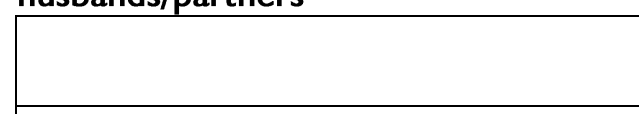 } & \multirow{2}{*}{ Odds Ratios (ORs) } & \multicolumn{2}{|c|}{ 95\% C.I. for EXP(B) } \\
\hline & & Lower & Upper \\
\hline \multicolumn{4}{|l|}{ Age in 5-year groups } \\
\hline $15-19$ & 0.768 & 0.430 & 1.374 \\
\hline $20-24$ & 0.726 & 0.479 & 1.099 \\
\hline $25-29$ & 0.715 & 0.496 & 1.032 \\
\hline $30-34$ & 0.886 & 0.618 & 1.271 \\
\hline $35-39$ & 0.822 & 0.567 & 1.192 \\
\hline 40-44 & 0.827 & 0.556 & 1.231 \\
\hline $45-49(\mathrm{RC})$ & 1.000 & & \\
\hline \multicolumn{4}{|l|}{ Region } \\
\hline North Central & $1.623 *$ & 1.050 & 2.510 \\
\hline North East & $7.967 * * *$ & 5.358 & 11.849 \\
\hline North West & 0.695 & 0.354 & 1.363 \\
\hline South East & $\left.2.16\right|^{* * * *}$ & 1.417 & 3.298 \\
\hline South-South & I.936*** & 1.302 & 2.879 \\
\hline South West(RC) & 1.000 & & \\
\hline \multicolumn{4}{|l|}{ Place of residence } \\
\hline Urban & 1.084 & 0.855 & 1.376 \\
\hline Rural (RC) & 1.000 & & \\
\hline \multicolumn{4}{|l|}{ Highest educational level } \\
\hline No education & $0.5 \mid 2 * *$ & 0.332 & .788 \\
\hline \begin{tabular}{|l|} 
Primary \\
\end{tabular} & 0.683 & 0.456 & 1.021 \\
\hline Secondary & 0.760 & 0.514 & 1.124 \\
\hline Higher (RC) & 1.000 & & \\
\hline \multicolumn{4}{|l|}{ Current marital status } \\
\hline \begin{tabular}{|l|} 
Married \\
\end{tabular} & $0.595 *$ & 0.374 & 0.947 \\
\hline Living with partner & 0.626 & 0.332 & 1.181 \\
\hline Widowed & 0.630 & 0.328 & 1.209 \\
\hline \begin{tabular}{|l|} 
Divorced \\
\end{tabular} & 1.260 & 0.659 & 2.408 \\
\hline No longer living together/separated (RC) & 1.000 & & \\
\hline \multicolumn{4}{|l|}{ Respondent currently working } \\
\hline No & $0.737 *$ & 0.564 & 0.964 \\
\hline Yes (RC) & 1.000 & & \\
\hline \multicolumn{4}{|c|}{ Experienced any less severe violence by husband/partner } \\
\hline No & $0.094 * * *$ & 0.072 & 0.121 \\
\hline Yes (RC) & 1.000 & & \\
\hline \multicolumn{4}{|c|}{ Experienced any severe violence by husband/partner } \\
\hline No & $0.773 *$ & 0.607 & 0.984 \\
\hline Yes (RC) & 1.000 & & \\
\hline \multicolumn{4}{|l|}{ Husband/partner drinks alcohol } \\
\hline No & $0.437 * * *$ & 0.348 & 0.550 \\
\hline Yes (RC) & 1.000 & & \\
\hline \multicolumn{4}{|l|}{ Respondent's father ever beat her mother } \\
\hline No & 0.751 & 0.533 & 1.059 \\
\hline Yes & 1.316 & 0.911 & 1.900 \\
\hline \multicolumn{4}{|l|}{ Don't know (RC) } \\
\hline Constant & 0.000 & & \\
\hline
\end{tabular}

$$
\text { *P }<0.05 \text {; ** } \mathrm{p}<0.01 \text {; **** } \mathrm{p}<0.00 \text { I }
$$

It is true for the whole population. Similarly, those who had experienced severe violence from their partners are more likely to hurt their partners physically because the OR for those who had not experienced severe violence is 0.773 which is less 1.000 of the RC (those who had experienced severe violence) and is significant $(p<0.05)$. The OR also falls within the lower and upper $\mathrm{Cl}$. 
Table 3 further shows that the OR $(0.437)$ of those whose husbands were not drinking alcohol is significant $(p<0.00 l)$ and less than that of reference category (those whose husbands were drinking alcohol) and therefore respondents whose partners drank alcohol are more likely to inflict harm physically on their partners.

From Table 3, it was demonstrated that age, type of place of residence and witnessing violence in one's parental home were not predictors of physical violence by women. The hypothesis that witnessing violence is a perfect predictor of violence is not validated by this analysis. The variable, respondent's father ever beat her mother was used to test the hypothesis which states that witnessing domestic violence among one's parents is a significant predictor of the occurrence of domestic violence by women against their partners. The hypothesis was refuted because its OR (I.3I6) was not significant.

\section{Discussion of results}

The survey revealed that $2.1 \%$ (468) of the women had physically hurt their husbands or partners when they were not being hurt by their husbands/partners. Literature has shown that many men have suffered intimate partner violence from their wives (Keen, 2006; Graham-Kevan, 2011; White, 2009; Rhymes, 2014), but there is a lot of conspiracy of silence shrouding the issue (James, 2003; Lupri and Grandin, 2004; Adebayo, 2014). This number was only for those women respondents who reported that they had actually inflicted harms on their husbands/partners when their male partners were not hurting them and there is good reason to think that this would have been underreported given that DV against a husband is perceived as an occurrence that is not normal (Shuler, 2010; Adebayo, 2014). If the survey had included those who were involved in mutual intimate partner violence (IPV) i.e. had ever hurt their husbands/partners when the men were hurting them i.e. during a fight or in retaliation, the number would have been greater than 468 . In the developed world, a significantly higher number of studies have documented the male victims of IPV. On the contrary, in this part of the world which is highly patriarchal, there is a lot of denial. Very little is known about the actual number of men who have been abused by their wives because men do not usually report about their abuse received from their wives (James, 2003; Adebayo, 20l4). Men do not report because of social stigma, preservation of male ego and other denigrations of their masculinity (James, 2003; Lupri and Grandin, 2004; Adebayo, 2014).
The study revealed that location where the respondents were interviewed was a significant predictor of violence by women. Women from the south east were found to be twice likely than south western women to inflict bodily harm on their partners. Similarly, women from the south-south zone were more likely than those from south west to do the same. Both findings were highly significant at $p<0.00 \mathrm{I}$. This could be explained by cultural variations between the regions (Dasgupta, 200I and 2002). It could be that women from these two zones were trapped in their abusive marriages to keep their families together and stay with their children because of their cultural expectations. Dasgupta (2002) and Swan (2006) have reported that women who were resilient in abusive relationships behave violently toward their partners to protect their children and themselves. They could also hit their husbands/partners in self defence. This is supported by reports of Swan and Snow (2003) and Swan (2006). They reported that many women mentioned self-defence as motive for use of violence against their husbands/partners. One limitation of the 2013 NDHS was that the respondents were not asked to provide reasons for assaulting their intimate partners physically when they were not being hurt by the men.

Secondly, women from the North-West and North-East were more likely to be violent than those from South West. Probably, they physically abused their husbands out of jealousy as many of them might be in polygynous marriages. Polygyny is still common in the Northern part of the country. Adebayo et al. (2010) have found in their study that polygynous family is one of the factors that provoke DV. Women in polygynous relationships are often suspicious of each other due to jealousy, perceived preference and search for husbands' attention (lliyasu et al) which may lead to DV especially when they all cohabit in the same house (Ashimi and Omole, 2015). Furthermore, the women might have perpetrated the DV in retaliation. Ashimi and Omole (2015) revealed that many of the women in their study who suffered DV were of Hausa/Fulani ethnic group from the North-West.

The data indicated that highly educated women were more likely than uneducated ones to commit violence against their husbands/partners. Highly educated women are likely to be empowered both economically and socially. They are more independent than uneducated women and therefore could afford to fight their partners without minding the consequences. They might also desire to control their partners as postulated by Goode (197I) and Bostock et al (2002 cited in Hyde-Nolan and Juliao, 20I2). On the contrary, poorly educated women 
suffer DV more than women with higher level of education (Envuladu et al., 20I2).

Marital status was found to be a predictor of inflicting physical hurt on the respondents' husbands or partners. It was revealed that women who were no longer living with their husbands and those who had separated from their relationships were more likely than currently married respondents to physically hurt their partners. This, perhaps, could be one of the reasons for their separation. Probably, they hurt their partners physically to get even with them. Swan et al (2008) suggest that retribution for real or perceived wrongdoing is a common motivator of women's violent behaviour. Forty-five percent of women in Swan and Snow's (2003) study stated that they had used violence to get even with their partners for something they had done, for hurting them emotionally or to retaliate for previous abuse and to punish them (Swan et al, 2008; Klein, 2009).

The survey further revealed that women who were working were perpetrators of violence against their partners. The explanation for this finding is similar to the one of education above where educated women were more likely than others to inflict harm on their partners. Employed women are more likely to be economically empowered and could capitalise on it to perpetrate such acts. Secondly, women are becoming bread winners in their homes currently and there seems to be a reversal of roles between men and their wives since the economic recession. It is probable that a substantial number of men are financially dependent on women now. Violence is seen as an outcome of the inequity of exchange (Goode, 197I). A female household head could disrespect or desire to control her husband/partner (Goode, 197I) and/or the husband could feel threatened and in order to assert himself in the family, would provoke his wife who could, out of anger and stress, hit him. Goode (197I) asserts that the decision making power within a given family derives from the value of the resources that each person brings to the relationship.

The study also found that respondents who had experienced both less severe and severe violence had inflicted harm on their husbands/partners. Studies have consistently shown that there is an association between victimization and perpetration of DV (Klein, 2009). Swan et al. (2008) opine that majority of domestically violent women have also experienced violence from their male partners. This is also demonstrated in the conceptual framework above (Dasgupta, 200I)

It was revealed in the study that those whose partners drank alcohol also perpetrated violence against their intimate partners. This could be as a result of husbands' misbehaviour after drinking or that the respondents perceived drinking as a waist of financial resources which could have been used to solve other competitive needs. Some women may get angry and frustrated when their partners engage in drinking excessive alcohol and men may be less capable of protecting themselves from assault when drunk. Straus (20II cited in Hoff, 20I2) asserts that the predominant immediate motives for violence by women, as well as men, are frustration and anger at some misbehaviour by the partners. Frustration and anger are efforts to coerce the partners into stopping some socially undesirable behaviours (in this case excessive alcoholic consumption) or to practice some socially desirable behaviours. Perhaps, after several warnings, complaints and reports to the family members, relatives and friends, the men did not stop drinking. The women decided to use coercive control to deal with the matter in their own way and by hitting their husbands/partners (Swan and Snow, 2003; Stuart et al, 2006; Bostock et al, 2002 cited in Hyde-Nolan and Juliao, 20I2). Goode (I97I cited in Hyde-Nolan and Juliao, 2012) states that abusers may use violence to control other less powerful members of the family from engaging in behaviours that they do not want. For instance, a wife, in an effort to control her drunken partner, may use violence to control him and also to prohibit him from drinking while establishing a demand for desirable behaviours to occur. Finally, it could also be that the condition i.e. husbands'/partners' drunken condition had driven the women to develop borderline personality disorders. Evidence has shown that one half of women perpetrators of violence against men have borderline personality disorders (Corry et al., 200I; Oregon Counselling, 2014)

\section{Conclusion and recommendations}

The research hypothesis stated that witnessing domestic violence among one's parents was a significant predictor of the occurrence of domestic violence by women against their husbands/partners. This hypothesis was not validated by this study. The findings indicated that women in the north-central, north-east, south-east and south-south, highly educated women, divorced/separated women, employed women, those whose husbands/partners drank alcohol and those women who had experienced domestic violence were likely to perpetrate violence against their husbands/partners.

Having shown that region is a major predictor of DV against men by women, it is recommended that the cultural context of DV against men be explored. We propose a qualitative study that seeks to show how variation in family structure, cultural beliefs, 
philosophy, cultural factors in nuptiality can influence the occurrence of DV against men. This is necessary because this study has shown that DV against men varies across regions which are rough culture/ethnic clusters within the country.

It is also important for marriage counsellors, NGOs with focus on DV and religious leaders to give attention to educating men and women on the dangers of DV, the need to report DV if and when it occurs, and the need for men to seek help when they are victimized by their spouses.

\section{Acknowledgement}

The authors will like to acknowledge and appreciate the permission given by the DHS Programme to analyse the data for this study.

\section{References}

Adebayo, A. A. (20/4). "Domestic Violence against Men: Balancing the Gender Issues in Nigeria" American Journal of Sociological Research, 4(I): |4-19, DOI: 10.5923/j.sociology.20140401.03

Adebayo, A. A., and Kolawole, T. O. (20|3). Domestic violence and death: Women as endangered gender in Nigeria. American Journal of Sociological Research, 3: 53-60

Adebayo, R. A., Okulate, G. T., Ladapo, H. T. O., and Lawal, R. A. (20I0). Prevalence and correlates of spouse violence among women in a primary health care facility in Lagos Nigeria. Nigerian Journal of Psychiatry, 8(3): 2-6.

Ashimi, A. O. and Amole, T. G. (2015). Prevalence and predictors for domestic violence among pregnant women in a rural community Northwest, Nigeria. Nigerian Medical Journal [serial online] 2015 [cited 2016 Jun 24];56:1।821. Retrieved from http://www.nigeriamedj.com/text.asp?2015/56/2/I 18/150696

Azhar, Z., Sohail, M. M., Yasin, G., Mahmoud, B., and Mushtaq, S. K. (20/2). Exploring socio-economic factors behind domestic violence against women in Sargodha district. International Journal of Asian Social Science, 2: 1617-1626.

Bandura, A. (1977). Social learning theory. Englewood Cliffs, NJ: Prentice Hall. Retrieved from

http://psychology.about.com/od/developmentalps ychology/a/sociallearning.htm, on Tuesday 6/10/15

Campbell, D. (2010). More than $40 \%$ of domestic violence victims are male, report reveals", The Guardian, retrieved from http://www.theguardian.com/society/2010/sep/05/ men-victims-domestic-violence, Tuesday, 6/10/15

Cheryl, H. (2002). "Domestic Violence" Encyclopaedia of Crime and Justice, The Gale
Group Inc. retrieved from http://www.encyclopedia.com/topic/Domestic_vi olence.aspx, 23/16/16

Creative Communications Group (2015). "Definition" Divorce online, retrieved from http://www.domesticviolence.org/definition/ on 20/10/15

Corry, C. E. (2002). Domestic Violence against Men" Equal Justice Foundation, retrieved from http://www.dvmen.org/dv-32.htm\#pgfld1615907

Corry, C. E., Pizzey, E. and Fiebert, M. S. (200I). "Controlling Domestic Violence against Men" Nuance No. 3, (17): 7I - 86, December 200I, retrieved from http://www.amen.ie/articles/corry.pdf

Dasgupta, S. D. (200I). "Towards an Understanding of Women's use of Non-lethal Violence in Intimate Heterosexual Relationships", Applied Research Forum of the National Resource Centre on Domestic Violence, retrieved from http://www.ncdsv.org/images/Womens_Use_of_V iolencel.pdf

Dasgupta, S. D. (2002). A framework for understanding women's use of nonlethal violence in intimate heterosexual relationships. Violence Against Women, 8: I364-I 389

Dienye, P. O. and Gbeneol, P. K. (2009). Domestic Violence against Men in Primary Care in Nigeria. American Journal of Men's Health, 3(4): 333-339

Dutton, D. G., Nicholls, T. L. and Spidel, A. (20/6). "Female Perpetrators of Intimate Abuse", Domestic Violence Research, retrieved from http://whiteribbon.org/domestic-violenceresearch/female-perpetrators-of-intimate-abuse/ on $16 / 6 / 16$

Envuladu, E. A., Chia, L., Banwat, M. E., Lar, L. A., Agbo, H. A., and Zoakah, A. I. (20|2). Domestic violence among pregnant women attending antenatal clinic in a PHC facility in Jos North LGA, Plateau State, Nigeria. E3 Journal of Medical Research, I: 063-068.

Ezeah, P. (20/3). "Socio-economic and cultural processes associated with domestic violence in rural Nigeria: A study of Uzo-Uwani Local Government Area of Enugu State". Bangladesh eJournal of Sociology, IO(I): 92-100.

Eze-Anaba, I. (2007). "Domestic violence and legal reforms in Nigeria: Prospects and challenges". Cardozo Journal of Law \& Order, 14: 21-59.

Federal Government Printer (FGP), (2007). "Legal Notice on publication of the details of the breakdown of the national and state provisional totals 2006 census" Federal Republic of Nigeria 
Official Gazette, No. 24, Vol. 94, Lagos: $15^{\text {th }}$ May 2007: B 175 - 198

Federal Ministry of Health (FMOH), (2010). Technical Report: The 2010 National HIV Sentinel Survey, Abuja: Office of the National Coordinator, National AIDS/STI Control Programme, Department of Public Health

Goode, W. J. (197I). "Force and violence in the family", Journal of Marriage and the Family, 33, 624-635.

Graham-Kevan, N. (20II). "The invisible domestic violence - against men" retrieved from

http://www.theguardian.com/commentisfree/201 I/ju $\mathrm{n} / 07 /$ feminism-domestic-violence-men on 28/10/15

Hidden Hurt Message Forum (20II). "Male Victims of Domestic Violence" Hidden Hurtretrieved from

http://www.hiddenhurt.co.uk/male_victims_of_do mestic violence.html

Hoff, B. H. (20/2). "National Study: More Men than Women Victims of Intimate Partner Physical Violence, Psychological Aggression. Over $40 \%$ of victims of severe physical violence are men". MenWeb on-line Journal (ISSN: 1095-5240 http://www.batteredmen.com/NISVS.htm)

Hyde-Nolan, M. E. and Juliao, T. (20I2). "Theoretical Basis for Family Violence" Jones and Bartlett Learning LLC, retrieved from http://samples.jbpub.com/9780763780340/80340 CH02 FINAL.pdf

Iliyasu, Z., Abubakar, I. S., Galadanci, H. S., Hayatu, Z. and Aliyu, M. H. (20/3). "Prevalence and risk factors for domestic violence among pregnant women in northern Nigeria", Journal of Interpersonal Violence, Vol. 28: 868 - 883.

James, T. B. (2003). "Domestic Violence against Men Is The Most Underreported Crime" Equal Justice Foundation, retrieved from http://www.dvmen.org/dv-32.htm\#pgfld1615907

Keen, C. (2006). "Women more likely to be perpetrators of abuse as well as victims", retrieved from http://news.ufl.edu/archive/2006/07/womenmore-likely-to-be-perpetrators-of-abuse-as-wellas-victims.html on $28 / 10 / 15$

Klein, A. R. (2009). "Practical implications of current domestic violence research: For law, Prosecutors and Judges", Special Report/Junes 09, Washington DC.: US Department of Justice Office Programmes, National Institute of Justice

Loue, S. (200I). Intimate Partner Violence: Societal, Medical, Legal and Individual Responses. New York: Kluwer Academic/Plenium Publishers
Lupri, E. and Grandin, E. (2004). "Intimate Partner Abuse against Men" National Clearinghouse on Family Violence. retrieved from http://web.archive.org/web/20090 I040742 I I/http ://www.phac-aspc.gc.ca/ncfv-

cnivf/familyviolence/pdfs/Intimate_Partner.pdf on I5/1/16

Morgan, A. and Chadwick, H. (2009). "Key issues in domestic violence" retrieved from http://www.aic.gov.au/publications/current\%20se ries/rip/I-I0/07.html on 28/10/15

National Domestic Violence Hotline (2015). "Domestic Violence" retrieved from http://www.justice.gov/ovw/domesticviolence\#dv, on $28 / 10 / 25$

National Population Commission (NPC) [Nigeria] and ICF Macro (2009). Nigeria Demographic and Health Survey 2008. Abuja, Nigeria: National Population Commission and ICF Macro

National Population Commission (NPC) [Nigeria] and ICF International. (20|4). Nigeria Demographic and Health Survey 2013. Abuja, Nigeria, and Rockville, Maryland, USA: NPC and ICF International.

Nnadi, I. (20/2). An insight into violence against women as human rights violation in Nigeria: $A$ critique. Journal of Politics and Law, 5(3): 48 - 56

Oregon Counselling (20|4). "About Domestic Violence against Men", retrieved from http://www.oregoncounseling.org/Handouts/Dom esticViolenceMen.htm

Population Reference Bureau (2015). 2015 World Population Data Sheet. Washington, DC: Population Reference Bureau.

Rennison, C. M. (2003). "Intimate Partner Violence 1993-200I" Bureau of Justice Statistics Crime Data Brief.U.S. Department of Justice. Retrieved from

http://www.bjs.gov/content/pub/pdf/ipv0I.pdf $19 / 6 / 16$

Rhymes, E. (20|4). "Woman as aggressor: The unspoken truth of domestic violence", Mintpress News, retrieved from http://www.mintpressnews.com/womanaggressor-unspoken-truth-domesticviolence// 96746/ on 8/8/15

Shuler, C. A. (2010). Male victims of intimate partner violence in the United States: Examination of the review of literature through the critical theoretical perspective, International Journal of Criminal Justice Sciences, 5 (I): 163 - 173

Smith, K. (Ed.). Coleman, K., Eder, S. and Hall, P. (20II). "Homicides, Firearm Offences and Intimate Violence 2009/10".Supplementary Volume 2 to Crime in England and Wales 2009/10 
(2nd Edition) Home Office. Retrieved from https://www.gov.uk/government/uploads/system/ uploads/attachment_data/file/ I I65 I2/hosb0 I II.P df 19/6/16.

Sommer, R. (1994). "Male and Female Perpetrated Partner Abuse: Testing a Diathesis-Stress Model", A dissertation presented to the University of Manitoba in fulfillment of the dissertation requirement for the degree of Doctor of Philosophy in the Interdisciplinary Doctoral Program

Stewart, A. (200I). "Domestic Violence: An Overview of Emerging Issues" Police Practice and Research: An International Journal, Vol. 2: 447460

Stuart, G. L., Moore, T. M., Gordon, K. C., Hellmuth, J. C., Ramsey, S. E. and Kahler, C. W. (2006). "Reasons for intimate partner violence perpetration among arrested women. Violence Against Women". PubMed Journal, 12(7): 609 621.

Swan, S. (2006). "The Development of a Theory of Women's Use of Violence in Intimate Relationships", Violence Against Women, Vol. 12 (II): 1026-1045, November 2006, Sage Publications, I0.1I77/107780I206293330, http://www.genderbias.net/docs/resources/guideli ne/The\%20Development\%20of\%20a\%20Theor y.pdf, 23/6/16

Swan, S. C. and Snow, D. L. (2003). "Behavioral and psychological differences among abused women who use violence in intimate relationships", Violence Against Women, Vol. 9:75-109

Swan, S. C., Gambone, L. J., Caldwell, M. A., Sullivan, T. P. and Snow, D. L. (2008). "A Review of Research on Women's Use of Violence With Male Intimate Partners", Violence victims, Vol. 23 (3): 301 $3 \mid 4$, http://www.ncbi.nlm.nih.gov/pmc/articles/PMC29 68709/, 19/6/16

Tenuche, M. (20I I). "The Burden of Marital Vows: A Study of Domestic Violence in Benue and Kogi States, North Central Nigeria" Journal of Research in Peace, Gender and Development, Vol. I(6):192-203 July 20II Available online@ http://www.interesjournals.org/JRPGD, $\quad$ (ISSN: 225I-0036)

UK Government (20/3). "Domestic violence: Guidance and support for the armed forces community" retrieved from https://www.gov.uk/guidance/ domestic-violenceand-abuse on $28 / 10 / 15$

UN Data (20I3). World Statistics Pocketbook, United Nations Statistics Division,Version v0.14.6 Beta, retrieved
http://data.un.org/CountryProfile. aspx?crName $=$ NIGERIA, 23/6/16

Weinberger, B. Z. (2015). "It's Time to Acknowledge Male Victims of Domestic Violence" retrieved from http://www.huffingtonpost.com/bari-zellweinberger-esq/its-time-to-acknowledgem b 8292976.html

White, C. (2009). "Domestic violence: Women abusers on the rise" News Online, 22 Jun 2009, retrieved http://www.abc.net.au/news/2009-0622/domestic-violence-women-abusers-on-therise// 327964

World Health Organization (2010). Preventing intimate partner and sexual violence against women: Taking action and generating evidence. Geneva, Switzerland: Author.

Young, C. (20|4). "The surprising truth about women and violence" retrieved from http://time.com/2921491/hope-solo-womenviolence/ on $28 / 10 / 15$

Yusuf, O. B., Arulogun, O. S., Oladepo, O., and Olowokeere, F. (20II). Physical violence among intimate partners in Nigeria: A multi level analysis. Journal of Public Health and Epidemiology, 3, 240247. 